\title{
Seeing Like a Protester: Nature, Power, and Environmental Struggles ${ }^{1}$
}

Marco Armiero

\section{Seeing nature through conflicts}

\begin{abstract}
"The more that [human-modified] nature is seen as the history of labor, property, exploitation, and social struggle, the greater will be the chances of a sustainable, equitable, and socially just future". James O'Connor ${ }^{2}$
\end{abstract}

Take a forest, for instance. What are we, as historians, supposed to see in it? For a long time historians have simply been blind towards nature; that forest has been invisible to us. Still, being able to see it has not necessarily meant understanding it. Focused only on market dynamics, extraction and transportation costs, some economic historians have looked at that forest as a "wood quarry", giving a onedimensional image to it and its history. Obviously, shifting from a narrow economic vision to a cultural or post-modernist one has not made the forest more visible. Thus the arrival of environmental history on the historiographical scene has represented a unique chance to see and understand that forest. Indeed, the question could be: what should an environmental historian see in that forest? The answer should be easy_-nature, of course. But things are more complicated than this. What is nature? What are its relationships with economy, culture, and society? In which ways have they worked historically? These questions remain.

In this article I argue that we can better see and understand the environment if we look at it through the lens of conflict. I will show that adopting a conflict-based approach can enlighten nature and society, thus exposing both. Speaking about social ecology, Ramachandra Guha stated that he saw it essentially as "a problem focus, albeit with important theoretical and methodological implications." ${ }^{\prime}$ I have a similar idea of a conflict-based approach to environmental history. In other words, I do not claim to offer here a new methodology; social and environmental historians, and even political ecologists, have been working on conflicts for a long time. While the percentage of social and natural disclosed by those stories has always been a matter of debate, what is still missing, in my opinion, is a discussion of the methodological opportunities and implications of a conflictbased approach precisely to overcome this society/nature dichotomy. A conflictbased approach can reveal the structure of power embodied in nature as well as the socially diversified contents of humans' agency. ${ }^{4}$ If Raymond Williams is correct in stating that human labour is so mixed with the labour and forces of the 
earth that it is impossible to separate them, ${ }^{5}$ we can conclude that nature is neither the backdrop nor the base buried under the sediment of social relations and cultural constructions; nature is mixed with them and we need to find the nature in society as well as the social in nature. I argue that studying environmental conflicts can lead us to this result without obliterating nature. A garbage dump in a neighbourhood, cancer in a body, the transformation of a forest into a wood quarry: these signs in the ecological landscape exhibit changes in technological/cultural systems; I argue that those signs also need to be interpreted as a manifestation of socio-ecological relations informed by power. I will illustrate that a conflict-based approach enables us to see these relations.

In what follows, I will analyze two case-studies from Modern Italy, moving from the second half of the nineteenth century to the present and address: 1) the end of common uses and the expropriation of local community rights in 1860 rural Italy, and 2) the struggles against incinerators and toxic waste in contemporary Naples. Quite dissimilar, these two cases exemplify the fruitfulness of a conflict-based approach, adaptable to various contexts. While the rural case shows that imposing the "rational" exploitation of a forest shaped not only nature but also society, the contemporary garbage struggle reveals that the distribution of power among social groups affects not only their social relations, but also the ecology of the urban/rural environments and, ultimately, of the human bodies inhabiting them. In both cases the natural and the social merge, demonstrating the conflict-based approach as not only a scholarly bridge between subdisciplines (social history, environmental history, and political ecology), but also a better tool to understanding the social and ecological inequalities of capitalistic societies. ${ }^{6}$

Methodologically, this article is deeply informed by my dual disciplinary identity as a social and environmental historian interested in political ecology. With this article I intend to contribute to the ongoing debate on the relationship between social and environmental history, proposing the conflict-based approach as a common ground between the two fields. The debate is a longstanding one, at least for environmental historians, but it has been receiving growing attention in the last few years. 'The upcoming international conference "Common Ground, Converging Gazes. Integrating the Social and Environmental in History”, devoted to this topic, is the most evident sign of a fresh interest in cross-fertilization between the two fields. ${ }^{8}$

Additionally, the rise of the Environmental Justice Movement (EJM) and of what Joan Martinez Alier has defined as the "Environmentalism of the Poor" has contributed to this merging of social and environmental issues. A different kind of environmentalism, rooted in social-ethnic conflict, focusing more on urban/industrial environments than on wilderness, striving to defend internal and external nature (i.e., both humans' and ecosystems' health), carries with it a demand for an environmental history attentive to socio-economic dynamics. Although the EJM is essentially a recent phenomenon within the larger history of 
environmentalism, ${ }^{10}$ it can reinterpret traditional struggles by providing new categories. Nevertheless, as Karl Jacoby has written, "the connection between social justice and environmental justice is undertheorized at present ... asserted rather than investigated". ${ }^{11}$

\title{
Trespassing
}

\begin{abstract}
"It will be found that the customs which are customs of the entire poor class are based with a sure instinct on the indeterminate aspect of property; it will be found not only that this class feels an urge to satisfy a natural need, but equally that it feels the need to satisfy a rightful urge."

Karl Marx, Debates on the Law on Thefts of Wood (1842)
\end{abstract}

Of the various forms of environmental conflict throughout history, the struggle against the privatization of common resources is certainly the one in which a connection with social conflict is most evident. Between Karl Polanyi's "commodification of nature" through enclosures and Garret Hardin's redeeming tale on privatization as the ultimate therapy to "the tragedy of the commons", there are the stories told by historians and social scientists who have tried to test these hypotheses empirically. ${ }^{12}$ And all of them are stories of conflict. Contrary to Hardin's thesis, the privatization of common property has never been the rational solution to all conflicts over natural resources; rather privatization of common property is itself strongly marked by conflict, both in the form of resistance to change from the lower classes and of competition for exclusive control among the elite. ${ }^{13}$ Empirically testing the results of the "privatization" of water in nineteenth-century Italy, for instance, Stefania Barca has recently shown how private property rights were inefficient both in reducing environmental disruption and in mitigating socio-ecological struggles. ${ }^{14}$

Marxist social historians have produced ample literature on peasant revolts and resistance; they have challenged the teleological approach and economism of those who regarded as inevitable the transition from common to private, from collective to individual. Examples include: Thompson's poachers' moral economy ${ }^{15}$; Wolf's peasant wars ${ }^{16}$; Hobsbawn's and Rudé's Captain Swing ${ }^{17}$; Bois's French farmers ${ }^{18}$; and the rural rebels of nineteenth-century Italy studied by several Italian historians. ${ }^{19}$ Nevertheless, these scholars have generally paid minimal attention to nature. ${ }^{20}$ In what way did those social conflicts also incorporate ecological conflict between different ways of understanding and using nature? Do those conflicts help us see in which ways power relations were reflected in the environment? Let us take an Italian forest, for instance.

In February 1860, somewhere in the Bosco Ragno, in the southern Italian Apennines: beating drums, a crew of peasants invaded the land "throwing out the contractors, devastating properties, stealing wood, and threatening foresters' 
lives". ${ }^{21}$ Unsatisfied, the mob moved through the nearby village and occupied the Town Hall. Revolution, finally? Not exactly. It was a restoration. The peasants were searching the local archives for an old parchment which would have proven their customary right to use the forest. What was happening in the Bosco Ragno was nothing more and nothing less than the usual struggle between different ways of using natural resources and thinking about property rights. ${ }^{22}$ The owner of the forest, the Marques d'Avalos, sensing imminent major political changes (in a few months the Kingdom of the Two Sicilies ${ }^{23}$ would be incorporated into the Kingdom of Italy), decided it was time to modernize the forests of the Italian South; prohibiting customary rights, affirming the exclusiveness of private property, and increasing profits became the face of this modernity. The Bosco Ragno, once a feudal possession of the D'Avalos family and consequently subjected to a complex web of communal uses, ${ }^{24}$ was finally managed according to the rules of scientific forestry. Good wood or new land-in the new forest-there was no longer room for multiple activities. The Bosco Ragno, destined in part to be ploughed, was divided into sections in which the rights to clear the land-completely or partially-were sold to contractors, intentionally chosen from villages other than the one closest to the forest. The system of logging in sections was substantially a form of privatization of the resource and implied forbidding access to the forest for pasture, for gathering wood and wild fruits. This system with its widespread deforestation created a more intensive use of the forest, the privatization of profits, and the socialization of losses. In ecological terms, the forest ceased to be a complex and cohesive whole of wood, leaves, grasses, fruits, and soil and instead became primarily a wood 'quarry'. The shift from the customary rights to the 'modern' uses excluded the inhabitants of the village of Scerni, those closest to the Bosco Ragno, who had previously been entitled to access to the forest. Indeed, the Marques d'Avalos deliberately selected contractors from other villages, thereby exploiting longstanding rivalries among communities. ${ }^{25}$ The contractors robustly defended their exclusive rights to the forest; their guards threatened to rape the women from Scerni if they found them collecting wood and fruits in the Bosco Ragno. Threatened by the fear of an attack on female honour and citing the authority of history in ancient documents, the villagers justified their actions; they portrayed themselves as self-defenders and peaceful people, blaming the contractors: "Those [the contractors], aimed by their self interests, exercise their rights to the extreme consequences, without the compassion that was used by the very owner." ${ }^{\prime 26}$

Appealing to the compassion of the owner against the cupidity of the contractors was a way for the peasants to express the clash between a traditional moral economy - represented by the paternalistic feudal owner-and the new market economy - embodied in the contractors. Indeed, the protesters envisioned their resistance to the market economy as a restoration of customary relationships with nature and with the owner, therefore as nothing revolutionary or illegal. 
While the local government supported the peasants' version of the facts, asserting that the crowd did not want to subvert social order, the owner denounced huge abuses in his forest and on his properties, implying the theft of wood and the destruction of documents. Although in court the Royal Judge decided not to proceed against the protesters, ${ }^{27}$ following a longstanding tradition of paternalistic alliance between the crown and the plebe in the Kingdom of Two Sicilies, in reality the d'Avalos family and its contractors won. Taken from the unwritten regulations of the moral economy, another piece of the world ended in the clutches of the market. The victory did not exclude margins of resistance. For a long time the Bosco Ragno was a contested space marked by the 'destructive habits' of the local people, or at least by narratives about those habits. It is difficult to say whether accusations of destructive behaviour were well-founded or simply part of the struggle. ${ }^{28}$ In fact, since the Bosco Ragno conflict had been a confrontation between different ways of thinking about property and its uses, the very definitions of abuse and crime were quite controversial. ${ }^{29}$ While in many cases the traditional activities were declared illegal and therefore harmful to the forest, it was also possible that the new forestry regime had changed the way of using the resource. Since there were no longer any commons to be protected and no common rules to be observed, the users could have acted merely as spoilers of the forest, taking as much as possible from it. Furthermore, damaging the forest was part of the struggle; describing it as the 'normal' outcome of common uses was simply a rhetorical expedient to reinforcing private property and decrying any other approach to accessing natural resources.

\section{A personal matter}

"The most concrete emblem of every economic cycle is the dump. Accumulating everything that ever was, dumps are the true aftermath of the consumptions, something more than the mark every product leaves on the surface of the earth".

Roberto Saviano ${ }^{30}$

Outside the rural world of the nineteenth century, in the streets and factories of the new industrial society, the gap between social and natural systems appeared radical, and conflict seemed to lose its connection with the ecological basis of class survival. In other words, while in rural uprisings there is an evident relationship between social systems and ecosystems, nature does not seem to be an issue in factory strikes, miners' riots, and the innumerable contemporary forms of urban protests studied by social and labor historians; alienation from nature, i.e., the separation of nature from work, powerfully analyzed by Richard White, ${ }^{31}$ conceals the relationship between those social conflicts and the environment. Nevertheless, occurrences in everyday life within urban and industrial environments have challenged this division; the health of nature has become the health of human nature 
in an entangled mix of places and people, of bodies and ecology. ${ }^{32}$ Rather than being relegated to the realm of environmentalism, the struggle for environmental health has become a personal matter as people have discovered the connections between their illnesses and conditions in their living and working environments. ${ }^{33}$ Those connections, as Martin Melosi has effectively demonstrated, have historically become evident in the politics of waste disposal..$^{34}$

In Italy as well, where environmentalism has always been a minority culture, traditionally devoted to defending historical/artistic heritage or "natural beauties", ${ }^{35}$ the current struggles over garbage disposal in cities and working conditions in factories ${ }^{36}$ have changed the purposes and practices of the environmentalist movement, connecting social and environmental justice.

Such is the case of the struggles over garbage disposal and incinerators in Campania. This chronic crisis is the by-product of the combination between the inefficiency and corruption of local institutions and the criminal activities of the Neapolitan mafia, the camorra. According to a recent survey from the Agency for Environmental Protection, 43 percent of all Italian contaminated sites are in Campania. ${ }^{37}$ There, the same agency has found around 1000 illegal dumps, most of them in the Naples hinterland, full of all kinds of toxic waste. "38 "King Midas": the public prosecutors could not have chosen a better name for their investigation. ${ }^{39}$ As in the mythological tale, the bosses of camorra have been able to transform even the garbage into gold, offering the disposal of toxic wastes for ten eurocents/kilo against the 20 to -60 eurocents/kilo on the legal market. ${ }^{40}$ According to Legambiente, one of the leading Italian environmentalist organisations, in 2007 the value from "eco-crimes" reached about 23 billion euros; it has never been so high before. ${ }^{41}$ While the camorra was filling Campania's territory with all kinds of toxins, institutions were unable either to stop the illegality or promote the regular management of urban waste.

Indeed, the Neapolitan crisis is not an "emergency", but a structural problem which has lasted for more than a decade, giving birth to a special agency: the Committee for the Waste Emergency in Campania (Commissariato di Governo per l'emergenza rifiuti in Campania, hereafter Cgrcampania), with an officer appointed by the national government and its own budget. ${ }^{42}$ Nevertheless, this special agency has produced extremely poor results. After more than ten years of Cgrcampania's activity, the Campania region has five million bales of garbage which should have produced energy but are instead in storage, ${ }^{43}$ and 1.5 billion euros have been squandered by the Cgrcampania. ${ }^{44}$

The Cgrcampania, the local government, and the FIBE Corporation, ${ }^{45}$ in charge of regional waste disposal, have focused their strategies essentially on the construction of a gigantic incinerator in Acerra, ${ }^{46}$ using the chronic "emergency" to impose their plan and appropriate the economic resources to dedicate to the crisis. ${ }^{47}$ Failure to promote a reliable recycling program and focusing on incinerators have reinforced doubts about the quality of waste destined to be burned and the 
kind of emissions which will be produced. Moreover, this governmental/corporate plan is inscribed within the net of illegality which is now widely known thanks to Roberto Saviano's powerful inquiry Gomorrah. In other words, the local government and the FIBE Corporation have chosen to build incinerators and dumps in areas already heavily contaminated by illegal toxics disposal. ${ }^{48}$

"Facing a series of diseases, which no physicians were able to explain," Giampiero A., a Neapolitan activist, recalled in his memoirs, "I started to develop a simple hypothesis: if the sheep in my town are contaminated by dioxin, then I can be contaminated too". ${ }^{49}$ Submitting himself to lengthy physical tests, Giampiero unfortunately discovered that he was correct. If the sheep-and the entire environment - are sick, humans cannot be healthy. Though causal links are not clear-cut, several studies show that this area has witnessed a significant increase of certain pathologies that could be related to toxic contamination. ${ }^{50}$ Furthermore, in this region the mortality rate due to liver cancer is 38.4 percent, compared to 14 percent on a national scale..$^{51}$

Clearly, locating the most dangerous activities in the "worst" places, that is, poorer, racialized, or already polluted areas, should have seemed the easiest solution; as it has always been. However, the struggles over incinerators and dumps in Acerra, Giugliano, and Serre, just as those in Warren County, North Carolina ${ }^{52}$ or in Los Angeles ${ }^{53}$ demonstrate the folly of assuming that these communities are too poor, too ignorant, or too polluted to react.

The forms of mobilization as well as the repertoire ${ }^{54}$ of collective actions have varied: non violent resistance to construction of waste disposal facilities, legal challenges, petitions to the European Union (EU) Parliament, demonstrations, and even violent urban guerrilla protests. Even though some groups of activists are particularly linked to specific idioms of protest, many times this same group has adopted different forms of resistance, moving from petitions to barricades. ${ }^{55}$ Obviously, the language of resistance is not independent of the language of repression/coercion. In fact, they correspond. ${ }^{56}$ In addition, the positionality of the protesters in their daily-life experiences, that is, their geographical/emotional distance from the epicentre of the disaster, also shapes their mobilization strategies. Living a few meters from a dump produces a different type of activist.

"Local activists", "intellectuals", ${ }^{58}$ and "anti-global students" of the Centri Sociali ${ }^{59}$ are the three segments of this new environmentalism. The differences among them are profound, regarding not only the form and language of their resistance but also their understanding of environmental inequalities and possible remedies. ${ }^{60}$ Science is generally relevant in their discourses, playing a major role in the mobilization of intellectuals, ${ }^{61}$ nonetheless, ideas about science are quite different among the activists. While the Centri Sociali are interested in a critique of the construction of scientific knowledge and its relationship to corporate/government power, ${ }^{62}$ local activists look at the experts with a mixed feeling of distrust and hope, but also seek independent scientific observers. 
Law, violence, and disobedience are other key issues that divide diverse types of activists; while some of them fight to enforce the law, thereby relying on its authority, others blame the law and its agencies, viewing them as a means of control and repression, and calling for disobedience. ${ }^{63}$ The level of violence tolerated and/or practiced by these groups varies. For all of them the particular struggle that they lead must be connected to a larger context; indeed none of the activists is a prisoner in his/her own backyard. Nevertheless, the global context is not the same for all of them. While the anti-global students are interested in building an anti-capitalistic continental coalition of workers and grassroots environmentalists,$^{64}$ the intellectuals rely on the EU bureaucracy ${ }^{65}$ and compare the Campania case with similar cases of mismanagement of urban garbage. ${ }^{66}$ Finally, the local activists move beyond their territorial struggles and build coalitions with other local groups; in other words, they picket not just in their territories but also in those of neighbouring communities. ${ }^{67}$

Recalling their personal experiences in the movement, most of the activists narrate the challenge of unifying diverse cultures and political practices. One activist underlines the difficulty of working together for non-politicized members of "civil society" and radical militants of the Centri Sociali. ${ }^{68}$ While a young woman laments her inability to be the "perfect activist" because of her middle-class lifestyle, ${ }^{69}$ another activist stresses the struggle for unity: "In respect to my previous political experiences," Anna T. says, "I was very struck by the fact that our group ... was formed of such various components: there were the Catholics, the grillini ${ }^{70}$, Marxist-Leninists, squatters, common people, and civil society". ${ }^{71}$ Attack Giugliano Fronte Popolare (Attack Giugliano - Popular Front, AGFP), the most radical and antagonistic group in the galaxy of local committees in what Saviano calls the "Land of Fires", ${ }^{72}$ has worked to involve the local Catholic church in the struggle, trying to reach "non-political people". ${ }^{73}$ In his account of the life at the Taverna del Re picket, Raffaele G., one of the leaders of AGFP says, "Maybe the people in our assemblies do not know anything about Marxism and they do not want to speak about general topics, but finally they are here". ${ }^{74}$ Raffaele now recounts how a woman with no political experience concludes their daily assembly with a formula that is becoming their new slogan: "Nun ci' a faccio "cchiu", the Neapolitan dialect for "I can't take it anymore". ${ }^{75}$ As Raffaele adds, "this is not orthodox but it is effective".

\section{Conclusion: Protesters, naturally}

"Protest and survive."

E. P. Thompson

Why do we need an environmental history attentive to the history of struggles? What happens when we look at nature as if power relations really mattered? This approach enriches both environmental history and social history. However, this 
outcome sounds extremely academic and limited. In the 'real world', beyond the boundaries of scholarly papers, the struggles for social and environmental justice, the anti-globalization movements and grassroots groups already overlap, overcoming frontiers and traditional divisions on issues and activism. When we do not recognize this reality, we fail as scholars. Environmental struggles have radically changed our idea of nature, reshaping the boundaries between artificial and natural, external and internal, and forcing us to reject nature as something separate from people, worth protecting only if it is wild, un-humanized, or uncontaminated. Actually, the idea that caring for nature is a luxury only for wealthy, white, and well-educated people has been the basis for discriminatory policies on waste disposal and factory siting. In the name of the "path of least resistance", poor communities have become the ultimate repository for every kind of undesirable activity, from landfills to incinerators. ${ }^{76}$ However, their resistance proves the assumption wrong; another environmentalism is not only possible, but already in motion. ${ }^{77}$ And, as Carolyn Merchant points out, this new environmentalism reveals that "the domination of nature entails the domination of human beings along lines of race, class, and gender"' ${ }^{78}$

In what way does this new environmentalism change our work as scholars? A group of nineteenth-century peasants occupying a forest shall not, in our work, become anti-globalists; but recognizing the social inscribed into the ecology of that forest in terms of class, property rights, and power struggles can give us a better understanding of what happened. In the Bosco Ragno the social tension between the former feudal landowner and local users reached its climax close to the time of a significant political transformation, namely, the incorporation of the South into the Kingdom of Italy. The affirmation of individual property rights over land affected both social relations between owner and users and ecological relations among the parties and natural resources. In February 1860 those relations became visible in the forest. While the Marques D'Avalos and his contractors were dividing the forest into logging sections and the people from the village of Scerni were resisting that transformation, the old forest with its ecological and social landscape was disappearing, replaced by a new one, modern and contested. Social relations among groups were reflected in the ways of accessing and using nature; changing them was not only a social process, but also an ecological one. The Bosco Ragno reflected this entangled web of power and resistance.

Hence, environmental conflicts work as a litmus test; they uncover what is normally hidden in the landscape. However, exposing power in nature, conflicts are not only passive recording devices. They also produce nature and "natural discourses". These conflicts create new landscapes and new socio-ecological relationships, as the Neapolitan case exemplifies. Until a few years ago, driving on the Doppio Senso Americano, ${ }^{79}$ the high-speed road connecting the "garbage towns" in Naples' outskirts, meant travelling through an ugly landscape with no points of orientation and no "nature". The conflict over garbage has reshaped that land- 
scape, producing a controversial sense of community and place. Now the landscape surrounding the highway reveals a story of violence, injustice, and resistance, while a threatening nature, concealed in the soil and the bodies of residents, seems to be everywhere. Mountains of burning garbage, barricades, abandoned quarries full of every kind of waste, and post-futurist ziggurats created by millions of bales of rubbish are the new points of orientation on the map of the Neapolitan disaster. ${ }^{80}$

This conflict has uncovered not only social injustice but also ecological inequity inscribed in the landscape. The dream of affordable housing has been transformed into a nightmare. Not only have the Neapolitan suburbs been built with no urban plan and no services, and in areas totally controlled by the camorra, but they literally rise from every kind of illegal waste and rest on the edge of noxious dumps. Both suburban and metropolitan people have realized that separating themselves from the socio-ecological relationship that has created that landscape is simply an illusion. The conflict has tragically reconnected city and country, metropolis and suburbs, humans with their external and internal nature. People in the suburbs have rediscovered the rural environment surrounding their homes, learning the inescapable interconnections among water, crops, animals, and waste. $^{81}$ In March, just as I was revising this article, the fear of dioxin pollution caused an international crisis in the exportation of buffalo mozzarella from Campania, requiring the direct intervention of the EU. ${ }^{82}$

One of the basic claims of environmental history, as well as of ecological economics, is that nature matters; it has not been easy to make this simple point. For a long time no one has wanted to listen to natural agency in human affairs, and the point still requires wide acceptance. Are we again shifting to social agency, abandoning the original claim on nature's agency? I have tried to demonstrate that this is not the point. Rather, if nature truly matters and society and economy are understandable only within a larger ecological context, it is shortsighted to consider power as if everything but nature matters. Nature will not be hidden again under social struggles but rather seen everywhere. Yes, nature really matters. Always, indeed.

\section{NOTES}

1 Many people have helped me write this article. I need to thank: the friends of Nancy Peluso's "LandLab" at UC Berkeley, and in particular Stefania Barca, Catherine Corson, Gail Hollander, Rod Nuemann, Nancy Peluso, and Johannes Stahl; Paolo Macry; Donald Worster; Massimo Menegozzo, Giacomo D'Alisa and the activists in Naples; two anonymous referees and the editors of Left History; last but not least Veronika Fukson for her patient help in improving and editing my English.

2 James O'Connor Natural Causes. Essays in Ecological Marxism (New York: The Guilford Press, 1998), 66.

3 Ramachandra Guha, "Introduction," in Social Ecology, ed. Ramachandra Guha (New Delhi: Oxford University Press, 1994), 7. 
4 Don Mitchell's The Lie of the Land. Migrant Workers and the California Landscape (Minneapolis-London: University of Minnesota Press, 1996) offers an excellent example of how a conflict perspective uncovers the power relations embodied in the environment.

5 Raymond Williams, Problems in Materialism and Culture: Selected Essays (London: Verso, 1980), 83.

6 In particular, political ecology has been the most attentive discipline to the analysis of environmental conflicts; Joan Martinez Alier's The Environmentalism of the Poor: A Study of Ecological Conflicts and Valuation (Northhampton, MA: Edward Elgar Publishing, 2002) is a deliberate attempt to consolidate the discipline through the cross-fertilization of political ecology, ecological economics, and environmental history.

7 I do not have enough space here to detail the entire debate on social and environmental history. Elisabeth Blackmar's "Contemplating the Force of Nature," Radical Historians' Newsletter 70 (1994) still stands as a "classic"-and rare-critique of environmental history from the social perspective; another basic reference is the largely quoted debate between Donald Worster and William Cronon published in The Journal of American History 76: 4 (1990). Some of the most influential contributors to this discussion are also worth noting and I add them here: Alan Taylor, "Unnatural Inequalities: Social and Environmental Histories," Environmental History 1 (1996); Karl Jacoby, Crimes Against Nature. Squatters, Poachers, Thieves, and the Hidden History of American Conservationism (Berkeley: University of California Press, 2001), mainly the introduction; Ted Steinberg, "Down to Earth: Nature, Agency and Power in History," American Historical Review 107 (2002); Ted Steinberg, "Fertilizing the Tree of Knowledge: Environmental History Comes of Age," Journal of Interdisciplinary History 35: 2 (2004); Linda Nash, "The Agency of Nature or the Nature of Agency?," Environmental History 10 (2005); Stephen Mosley, "Common Ground: Integrating Social and Environmental History," Journal of Social History 39:3 (2006); Karl Jacoby, "Classifying Nature: In Search of a Common Ground Between Social and Environmental History," in Situating Environmental History, ed. Ranjan Chakrabarti (New Delhi: Manohar Publishers \& Distributors, 2007).

8 "It is clearly time for environmental history to engage more fully with the tools, methods, and concepts of social and economic history-and vice versa. This is not to say that there has been no progress in establishing common ground, but we still need to bring these fields into closer communication, for their mutual benefit;" from the call for papers of the conference, in <http://crh.ehess.fr/document.php?id=944> (1 September 2007).

9 I cite here only a few among the most recent examples of socio-environmental history stemming from the EJM experience: Andrew Hurley, Environmental Inequalities: Class, Race, and Industrial Pollution in Gary, Indiana, 1945-1980 (Chapel Hill: University of North Carolina Press, 1995); David Naguib Pellow, Garbage Wars: The Struggle for Environmental Justice in Chicago (Cambridge, MA: The MIT Press, 2002); Gregg Mitman, Michelle Murphy, and Christopher Sellers eds., Landscapes of Exposure: Knowledge and Illness in Modern Environments (Chicago: University of Chicago Press, 2004); Elizabeth D. Blum, Love Canal Revisited: Race, Class, and Gender in Environmental Activism (Lawrence: University Press of Kansas, 2008).

10 Underlining the "rich and diverse history that had previously bridged social and eco- 
logical themes", Robert Gottlieb agreed that only in the 1980s did the connection between them become stronger and more explicit; in Environmentalism Unbound. Exploring New Pathways for Change (Cambridge, MA: The MIT Press, 2006), 53. On the connections between urban and social reformers and a different kind of environmentalism focused on social issues rather than on wilderness, see Martin Melosi, Garbage in the Cities: Refuse, Reform, and the Environment, 1880-1980 (College Station, TX: Texas A\&M University Press, 1981; reprint, Pittsburgh: University of Pittsburgh Press, 2005).

11 Jacoby, Classifying Nature, 54.

12 Karl Polanyi, The Great Transformation: The Political and Economic Origins of Our Time (Boston: Beacon Press, 2001; reprint, first edition 1944); Garret Hardin, "The Tragedy of the Commons," Sciences 162 (1968).

13 In the longstanding debate on property rights and Hardin's thesis refer to E. Ostrom et al., eds., The Drama of the Commons (Washington, DC: National Academy Press, 2002); on conflicts about commons Michael Goldman, ed., Privatizing Nature: Political Struggles for the Global Commons (New Brunswick: Rutgers University Press, 1998). A rich bibliography on the theme and many online materials are on the web site of the International Association for the Study of Common Property (IASCP) at $<$ http://www.iascp.org/>.

14 Stefania Barca, "Enclosing the River: Industrialisation and the 'Property Rights' Discourse in the Liri Valley (South of Italy), 1806-1916," Environment and History 13:1 (2007): 3-23.

15 Edward P. Thompson, Whigs and Hunters: The Origin of the Black. Act (London: Allen Lane, 1975).

16 Eric R. Wolf, Peasant Wars of the Twentieth Century (New York: Harper \& Row, 1969).

17 Eric J. Hobsbawn and George Rudé, Captain Swing (New York: Norton, 1968).

18 Paul Bois, Paysans de l'Ouest : Des structures économiques et sociales aux options politiques depuis l'époque révolutionnaire dans la Sarthe (Le Mans: Vilaire, 1960).

19 Among others: Franco Molfese, Storia del Brigantaggio Dopo l'Unitá (Milan: Feltrinelli, 1972); Piero Brunello, Ribelli, Questuanti e Banditi: Proteste Contadine in Veneto e in Friuli, 1814-1866 (Venice: Marsilio, 1981). For an environmental history perspective on this theme, see Marco Armiero, "Ambienti in bilico," in Quando lo Stato Crolla, ed. Paolo Macry (Naples: Liguori, 2003).

20 A stronger attention to ecology is in some social scientists works, as, for instance, James Scott, Weapons of the Weak: Everyday Forms of Peasant Resistance (New Haven: Yale University Press, 1976); Nancy L. Peluso, Rich Forests, Poor People: Resource Control and Resistance in Java (Berkeley: University of California Press, 1992).

21 Naples National Archive - Ministry of Police (NNA-MP), Reale officina del telegrafo elet trico, Gaetano Bernardini al ministero di polizia (Telegram from Gaetano Bernardini to the Minister of Police), Vasto 25 February 1860, 1560/3085.

22 I have detailed the conflicts over forests in the nineteenth-century southern Apennines in my book Il Territorio Come Risorsa. Comunità, Economie e Istituzioni nei Boschi Abruzzesi, 1806-1860 (Naples: Liguori, 1999).

23 The Kingdom of Two Sicilies included the entire southern part of the Italian peninsula, from Sicily to the border with the Vatican State, north of Naples.

24 On the relevance of the feudal system in the moral economy of Italian southern peas- 
ants see Marta Petrusewicz, Latifundium: Moral Economy and Material Life in a European Periphery (Ann Arbor: University of Michigan Press, 1996).

25 These struggles among communities were documented largely by the Bulletin of the Feudal Commission (Bollettino della Commissione Feudale), which collected information on all conflicts concerning the abolition of feudalism in Southern Italy.

26 NNA-MP, l'intendente al ministero di polizia (Governor's letter to the Minister of Police), Chieti 2 March 1860, 1560/3085.

27 NNA-MP, l'intendente al ministero di polizia (Governor's letter to the Minister of Police), Chieti 28 February 1860, 1560/3085.

28 On the difficulty of distinguishing between crime as protest and crime only for personal gain, see Peluso, 14.

29 'Unauthorized users are called 'poachers', 'timber thieves', or 'squatters'; these labels are the ideological creations of such laws of exclusion”. Peluso, 12.

30 Roberto Saviano, Gomorrah (New York: Farrar, Straus and Giroux, 2007), 285.

31 Richard White, "Are you an Environmentalist or Do You Work for a Living?," in Uncommon Ground: Toward Reinventing Nature, ed. W. Cronon (New York: W. W. Norton, 1995).

32 On this see Linda Nash, Inescapable Ecologies: A History of Environment, Disease, and Knowledge (Berkeley: University of California Press, 2006); Ellen Stroud, "Dead Bodies in Harlem. Environmental history and the Geography of Death," in The Nature of Cities, ed. A. C. Isenberg (Rochester: Rochester University Press, 2006), 62-65.

33 On relations between personal engagement and political militancy, especially among women, see Cynthia Hamilton, "Concerned Citizens of South Central LA," in Unequal Protection. Environmental Justice and Communities of Color, ed. R. D. Bullard (San Francisco: Sierra Club, 1994), 217.

34 Melosi, Garbage, especially chapters seven and eight.

35 On the history of Italian environmentalism, see James Sievert, The Origins of Nature Conservation in Italy (New York: Peter Lang, 2000).

36 On workers' struggles for health and environment in Italy, see Stefania Barca, "Health, Labor, and Social Justice. Environmental Costs of the Italian Economic Growth, 1958-2000," in Agrarian Studies Colloquium, at < http://www.yale.edu/agrarianstudies/papers/26italiangrowth.pdf> (19 May 2008); Felice Casson, La Fabbrica dei Veleni (Milan: Sperling \& Kupfer, 2007); Giulio Di Luzio and Gianfranco Bettin, I Fantasmi dell'Enichem: La Lezione di Civiltà di un Operaio del Petrolchimico di Manfredonia (Milan: Baldini Castoldi Dalai editore, 2003).

37 In 1998 the Parliamentary Committee on the waste cycle labelled the Campania region as the "trash can of the country", using the data collected by the prosecutors in the investigation called "Adelphi". In Commissione Parlamentare d'inchiesta sul ciclo dei rifiuti e sulle attività illecite ad esso connesse (hereafter CPR). Relazione sulla Campania Relatore: Deputato Massimo Scalia, XXIII/12 (Rome: Stabilimenti Tipografici Carlo Colombo, 1998).

38 CPR, Resoconto stenografico della Commissione d'inchiesta sul ciclo dei rifiuti, Seduta del 7/4/2004 Audizione del sostituto procuratore della Repubblica presso il tribunale di Santa Maria Capua Vetere, Donato Ceglie.

39 According to the prosecutor Maria Cristina Ribera, this traffic of toxics yielded over 3300000 euros and involved about 40000 tons of refuse. In Procura della 
Repubblica presso il Tribunale di Napoli, Richiesta di rinvio a giudizio, al Giudice per l'udienza preliminare presso il Tribunale di Napoli, procedimento penale n. 50358/06 RGNR (Indictment, Court of Naples, prosecution no. 50358/06). I am grateful to Dr. Maria Cristina Ribera for her help.

40 Data from the investigation on eco-mafia, code-named "Houdini" (2004). Information quoted on the Neapolitan website of Indymedia <http://napoli.indymedia.org/node/476> (19 May 2008).

41 Enrico Fontana, "Presentazione," in Rapporto Ecomafia 2007. I Numeri e le Storie della Criminalità Ambientale, ed. Osservatorio Nazionale Ambiente e Legalità di Legambiente (Milan: Edizioni Ambiente, 2007), 13.

42 Cabinet order, 11 February 1994.

43 According to the Committee investigations, the bales of garbage do not meet the requirements for burning: "They contained too high a percentage of both arsenic and humidity, and entire objects have been found in them, for instance, a wheel with rim and tire, which proves the absence of any kind of screening”. In CPR, XXIII/12, 32.

44 Daniela De Crescenzo, "La Compagnia delle Ecoballe," Narcomafie Luglio/Agosto 2007. The Corte dei Conti (the Italian institution for safeguarding public finance) has stigmatized the waste of public money made by the Cgrcampania with sentence no. 4174/07, Corte dei Conti - Sezione Giurisdizionale per la Regione Campania.

45 FIBE is an international holding company formed by Fisia, Impregilo, Babcock, and Evo Oberhausen which was awarded the contract to manage waste disposal in Campania. Now, Impregilio has acquired Babcock's shares, controlling the majority of the holding. See Alessandro Iacuelli, "Le Mani nei Sacchi," Carta 27 (2007). FIBE won the award due to its low cost projections and despite a poor rating on the technical evaluation of its projects. See Gabriella Gribaudi, "Il Ciclo Vizioso dei Rifiuti Campani," Il Mulino 1 (2008).

46 It is worth noting that the contract gives FIBE the right to choose where to build the incinerators.

47 The CPR and other inquiries stress the use of the "emergency" budget to create jobs and reinforce patronage networks. This is the case, for instance, for the more than 2000 workers employed in the recycling process for jobs which have never started; in Gribaudi, 12. The Cgrcampania and the corporation in charge of waste management in Campania are currently under prosecution for environmental disaster and fraud; unfortunately, the 414 pages of accusations written by the public prosecutor Rosanna Saraceno are still confidential.

48 In 2000, 61 municipalities between Naples and Caserta were included in the national inventory of highly contaminated sites because they had illegal toxic landfills. See Renato Pizzuti, Lucia Martina, and Michele Santoro, "Stato di Salute della Popolazione e Discariche di Rifiuti: L'Esperienza della Campania," in Indagini Epidemiologiche nei Siti Inquinati: Basi Scientifiche, Procedure Metodologiche e Gestionali, Prospettive di Equità, eds. F. Bianchi and P. Comba (Rome: Istituto Superiore di Sanità, 2006), 122.

49 Giampiero A., My Experience in the Movement, in Archivio della Conflittualità Ecologica (ACE), a written memoir in the author's possession. The ACE is my proposed oral history project, a collection of stories from activists in the environmental struggles in contemporary Italy. I thank Dr. Giacomo D'Alisa, scholar and activist, for helping me with this project. Without his contribution, I would never have started it. In this paper 
I use the first stories we have collected for the project.

50 Organizzazione Mondiale della Sanità, Istituto Superiore di Sanità, Consiglio Nazionale delle Ricerche, Regione Campania, Trattamento dei Rifiuti in Campania: Impatto sulla Salute Umana. Studio Pilota, <http://www.protezionecivile.it/cms/attach/editor/rischi-nucleare/Sintesi_dei_risultati_e_indicazioni_preliminaripdf $>$ (19 May 2008); Pienluigi Altavista et al., "Mortalità per causa in un'area della Campania con numerose discariche di rifiuti," Epidemiologia e prevenzione 6 (2004), 314.

51 Simona Brandolini, "In Campania 250 Mila Persone Avvelenate dai Rifiuti," Corriere del Mezzogiorno, 17 May 2007.

52 Robert D. Bullard, "Environmental Justice in the 21st Century: Race Still Matters," Phylon 49: 3-4 (2001).

53 Giovanna Di Chiro, "Nature and Community: The Convergence of Environment and Social Justice," in Uncommon Ground: Rethinking the Human Place in Nature, ed. by W. Cronon (New York: W.W. Norton, 1996).

54 I am referring here to Charles Tilly's idea of repertoire in collective action; for a short introduction, see his "Collective Action" in Encyclopaedia of European Social History from 1350 to 2000, vol. 3, ed. P. N. Stearns (Detroit: Woodbridge Charles Scribner's Sons, 2001).

55 This is the case of Attack Giugliano-Fronte Popolare which has submitted a petition to the EU Parliament without renouncing strong actions to block the access to dumps. See Petizione alla Commissione Europea Salute e Ambiente (Petition to the EU Environmental Commission), 10 July 2007, in possession of the author. References to their 'stronger' forms of resistance are to the messages in their email list (presidiotavernadelre@libero.it) and to personal communications with Raffaele G.

56 The protesters speak about the massive presence of riot police as a "provocation", pointing out that the state has never used such repressive apparatus to protect their territories from the camorra toxics dumping. See the interview with an anonymous activist at <http://napoli.indymedia.org/node/238> (19 May 2008). A classic example of feedback between police repression and protesters' anger occurred on 12 May 2007 in Serre, when the Police attacked the picketers during a truce arranged by the Chair of the Cgrcampania and the protesters. See Massimo Ammendola, "L'assedio di Serre. Cronaca della Resistenza Contro la Farsa della Politica," Bollettino dell'Assise, May 2007.

57 By local activists I mean groups of self-organised citizens who live in the areas most heavily affected by the garbage crisis. They generally use non-violent forms of resistance to block trucks carrying garbage/materials for the construction of waste disposal structures. Pickets are their characteristic form of protest.

58 Here I am referring to the Assise della Città di Napoli e del Mezzogiorno (The Permanent Assembly of the City of Naples and Southern Italy), the most influential and active group of professionals and academics engaged in the struggles over garbage in Naples. The Assise was called for the first time in 1991 to fight against a massive urban development in downtown Naples that would have dramatically affected the historical features of the area. It was called again in 2005 to oppose the privatisation of the water supply in the district of Naples.

59 The Centri Sociali (Social Centers) are old, abandoned buildings occupied by young activists and transformed into centres for political, cultural, and recreational activities. On 
this experience see Pierpaolo Mudu, "Resisting and Challenging Neoliberalism: The Development of Italian Social Centers," Antipode 36: 5 (2004); Massimo Rispetto, a documentary directed by Paolo Virzì, <http://it.video.yahoo.com/video/play?vid=187751\&fr=> (19 May 2008). On anti-globalisation movements and the environment see Carolyn Merchant, Radical Ecology. The Search for a Liveable World (New York - London: Routledge, 2005; first edition 1992), 223-247.

60 Schematically, we may say that for local activists it is a matter of arrogance of the metropolis and their inhabitants, for the Centri Sociali a by-product of the capitalist way of production, while the intellectuals stress the corruption and inefficiency of the local government.

61 The Assise's website and periodical publication are rich with scientific papers: Alberto Lucarelli (jurist), "Ripartire dalla Costituzione," Bollettino dell'Assise (hereafter BA) January 2007; “Gestione Rifiuti: La Strumentalizzazione dell'Emergenza,” BA May 2007; "Tutela dei Diritti Fondamentali e Diritto di Resistenza," BA May 2007; "Profili di Illegittimità ed Inopportunità del Piano Regionale dei Rifiuti della Campania;" "Governare e Gestire la Raccolta Differenziata;" "Il Governo dei Rifiuti in Campania," BA September 2007; Franco Ortolani (geologist), "Il Sele per la Vita," BA February 2007; Id., "Serre, una Nuova Discarica tra il Fiume Sele e l'Oasi Naturalistica," BA May 2007; Benedetto De Vivo (geologist), "Rischio Vulcanico e Problema Discariche," BA May 2007; Giuseppe Messina (agronomist), "Lo Uttaro: Storia di una Bugia e di un Disastro Ambientale Annunciato," BA July 2007; Patrizia Gentilizi (oncologist), "Inceneritori: Anche a Forlì un Dibattito Rovente," BA July 2007; Antonio Marfella (oncologist), "Il Trucco dell'Inceneritore di Acerra," BA June 2007; Giuseppe Comella (oncologist), "Inceneritori e Danni alla Salute," BA February 2007.

62 On this, see the experience of the Laboratori dei Saperi Sociali (Social Knowledges Labo ratories) at <http://www.noglobal.org/nato/nellarete/labsap/2gg.htm> (19 May 2008).

63 Generally speaking, for the Assise, since the garbage crisis is essentially the result of illegalities, the solution is to restore law (and mainly the fundamental law of the state, that is, the Constitution). Instead, for the Centri Sociali the crisis is the product of capitalism which makes and enforces the law. More than restoring law, they are interested in disobeying it. Local activists have varied positions on law and disobedience, using the judicial system to affirm their rights, but also practicing disobedience against police repression.

64 "The core of our strategy must be a new alliance among workers, immigrants, local groups, and environmentalists who want to defend health, security in the factories, and ecological relations in their territories. ... The capital vs. labor conflict and the capital vs. nature conflict are interdependent and the movement needs to connect them"; in a document produced at the national conference of local groups held in Rome Centro Sociale Il Rialto Occupato on 14 December 2002, < http://www.inceneritori.org/sab14dic.doc> (19 May 2008). The same contents are expressed in Chart of Florence. Blueprint of local groups to escape from the Europe of waste. 8 November 2002, Colonnata di Sesto Fiorentino (Florence), <http:/ www.inceneritori.org/piatRifiutiFSE.doc> (19 May 2008).

65 Appello per l'Europa (Petition to the EU) at <http://www.napoliassise.it/appeuropa.pdf > (19 May 2008). 
66 See for instance the articles on Vienna and Brescia incinerators in the Assise BA: Wolfgang Kaltenbacher, "Vienna si è Fermata a Metà Strada," BA, March 2005; Patrizia Gentilini, "Inceneritori: Anche a Forlì un Dibattito Rovente," BA, July 2007.

67 The most relevant among these coalitions are: Patto di Mutuo Soccorso (Mutual Aid Agreement); Rete Campana Comitati Difesa Salute e Ambiente (Campania Network of Committees in Defence of Health and the Environment), the national network Rifiuti Zero (Zero Garbage), and the Comitato Allarme Rifiuti Tossici (the Committee on Toxic Wastes).

68 Quincas l'acquaiolo (pseudonymous), Autobiography of a Conflict, in ACE, written memoirs in possession of the author.

69 "My clothes were not right, I did not wear old jeans and this did not work at all. I did not use dialect and my Italian seemed too refined. Finally my place, where we used to have our first meetings: its marble floor on which I asked them not to trash their butts ..."; in Paola R., My Experience in the Movement, ACE, written memoirs in possession of the author.

70 Anna is speaking about people linked to the ve ry popular Italian comic showman Beppe Grillo (from this "grillini") who is the leader of a movement characterised by a strong critique of the political establishment. On 8 September 2007 Grillo launched his movement with happenings in several Italian cities. On this experience see: Ian Fisher, "In a Funk, Italy Sings an Aria of Disappointment", New York Times, 13 December 2007, <http://www.nytimes.com/2007/12/13/world/europe/13italy.html> (19 May 2008); Tom Mueller, "Beppe's Inferno. A Comedian's War on Crooked Politics", New Yorker, 4 February 2008, <http://www.newyorker.com/reporting/2008/02/04/080204fa_fact_mueller?printable=true> (19 May 2008).

71 Anna T., My Experience in the Movement, ACE, written memoirs in possession of the author.

72 Roberto Saviano has defined the area around the towns of Giugliano, Villaricca, and Qualiano, just outside of Naples, as the "Land of Fires", referring to the camorra's practice of burning toxic waste. In Gomorrah, 282-301.

73 Raffaele G., My Experience in the Movement, ACE, written memoirs in possession of the author. As "non-political people" they mean those with no strong ideological identities who have never been involved directly in political/community activities before.

74 It is worth noting that Raffaele mentioned the assembly members' lack of knowledge about Marxism, neglecting mentioning environmentalism.

75 Raffaele G., My experience.

76 Robert D. Bullard, "Environmental Justice in the 21st Century: Race Still Matters,", 167.

77 Marco Armiero, "Un altro ambientalismo è possible. Intervista con Joan Martinez Alier," I Frutti di Demetra. Bollettino di storia e ambiente 13 (2007).

78 Merchant, 1.

79 The United States Army built this high-speed road during the Anglo-American occupation of the region from 1943 to 1945; hence the road is known as the American road.

80 To have an idea of those ziggurats, see the AGFP's video-documentary "Le Piramidi di Giugliano," broadcast on You Tube < http://it.youtube.com/watch?v=SZVaQt24hA4> (19 May 2008). 
81 In 2002-2003 several sheep and buffalo farms had to slaughter their cattle and close due to the high concentration of dioxin in the animals' blood and milk products. The farms also closed to prohibit access to pasturelands. On dioxin contamination and sheep farming in this area, see: L. Iannuzzi et al., "Chromosome Fragility in Two Sheep Flocks Exposed to Dioxins During Pasturage," Mutagenesis 19: 5 (2004); A. Perucatti et al., "Increased Frequencies of Both Chromosome Abnormalities and SCEs in Two Sheep Flocks Exposed to High Dioxin Levels During Pasturage," Mutagenesis 21: 1 (2006). Less "scientific" but very effective was the television documentary "Allame Cibo Avvelenato," first broadcast 15 December 2007 by La7 Network, available on line at < http://www.la7.it/blog/post_dettaglio.asp?idblog=ILARIA_DAMICO_-_Exit_15\&id=1509> (19 May 2008).

82 David Charter, "Buffalo Mozzarella in Crisis After Pollution Fears at Italian Farms," The Times, 29 March $2008<$ http://www.timesonline.co.uk/tol/life_and_style/food_and_drink/article3643079.ece> (19 May 2008); Michael McCarthy and John Phillips, "Italy's Toxic Waste Crisis, the Mafia and the Scandal of Europe's Mozzarella," The Independent, 22 March 2008, $<$ http:/ / www.independent.co.uk/news/europe/italys-toxic-waste-crisis-the-mafia-ndash-andthe-scandal-of-europes-mozzarella-799289.html> (19 May 2008). 